\title{
The Social Multiplier and Labor Market \\ Participation of Mothers
}

\author{
By Eric Maurin and Julie Moschion*
}

\begin{abstract}
:
In France, as in the US, a mother's labor market participation is influenced by the sex composition of her two eldest siblings. This paper shows that it is also affected by the sex composition of the eldest siblings of the other mothers living in the same close neighborhood. Using the sex composition of neighbors' eldest siblings as an instrumental variable, we identify a significant elasticity of own labor market participation to neighbors' participation. We present supportive evidence by comparing the estimates under two regimes for family benefits (preand post-1994 reform) and using quarter of birth as an alternative instrument.
\end{abstract}

JEL Codes: J16, J22

There is a large and still growing body of studies that explore the effect of neighbors on individual decisions. The influence of neighbors can amplify the effect of small changes in the distribution of private incentives and resources. This amplification is known as a "social multiplier" and represents one important reason for the attention given to neighborhood effects in the literature (Russell Cooper and Andrew John 1988; Charles F. Manski 1993; and Edward L. Glaeser, Bruce L. Sacerdote, and Jose A. Scheinkman 2003). For example, supporting a few women in finding work may lead their neighbors to do the same and have a very large and persistent social effect. From a theoretical viewpoint, these imitative behaviors may reflect an intrinsic desire to behave like others. It may also be due to interactions in the constraints that neighbors face, so that the indirect utility of a given behavior (for example, not working) depends on whether close neighbors do the same. It may also reflect interactions in information transmission, so that the choices of any single person modify the information available to all her neighbors.

These effects have long been identified as a potential explanation for the puzzling variations in labor market participation across subgroups of workers, across time periods, or across areas (Alberto Alesina, Glaeser, and Sacerdote 2006). Empirical

* Maurin: Paris School of Economics, 48 Bd Jourdan, 75014, Paris, France (e-mail: eric.maurin@ens.fr); Moschion: Paris School of Economics, 106-112 Bd de L’Hôpital, 75013, Paris, France (e-mail: julie.moschion@ dares.travail.gouv.fr). We thank participants at the "Social Interactions and Network" seminar in Paris, at the CREST econometric seminar in Paris, at the European meeting of the Econometric Society in Vienna, at the annual meeting of the French Economic Association in Paris, and at the meeting of the "Coalition Theory Network” in Warwick for helpful comments. 
evidence remains very weak, however. ${ }^{1}$ Women living in the same close neighborhood tend to make similar participation decisions. It is unclear, however, whether this is because they influence each other or because neighbors typically share the same background and the same preferences.

This paper makes use of the French Labor Force survey (LFS) to address this question and to provide estimates of the causal effect of a mother's decision to participate in the labor market on the participation decisions of the other mothers living in the same close neighborhood. The French LFS enables us to identify the influence of close neighbors because of the nature of the data collection. The sampling units consist of areas of about 20 adjacent households. It provides us with a large sample of mothers and detailed information on all the other mothers living in the same small area. This specific cluster sampling is uniquely suited to our research question. ${ }^{2}$

With respect to identification, our first strategy is based on the sex composition of the two eldest siblings of the families. In an influential contribution, Joshua D. Angrist and William N. Evans (1998) use the sex composition of the two eldest siblings as an instrumental variable (hereafter, the children sex-mix variable). They use this instrument to construct estimates of the causal effect of family size on mothers' labor market participation. In this paper, we first show that the sex-mix instrument has the same significant reduced-form effect on mothers' labor supply in France as in the United States. In contrast, we show that the sex-mix variable has no perceptible influence on neighborhood choice. Also, there is no significant correlation between the sex mix of a mother's children ("mother's children sex mix") and the observed demographic characteristics of the other mothers living in the same neighborhood. Given these facts, the observed shifts in the proportion of "same-sex" siblings' families across small neighborhoods are interpretable as quasi-experimental random shocks to the proportion of close neighbors participating in the labor market. Interestingly enough, the survey used in this paper shows that these shocks actually influence mothers' behavior. A mother's probability of labor market participation is significantly higher when the other mothers in her close neighborhood have "different-sex" siblings than in the opposite case. This difference is observed regardless of whether her own eldest siblings are "same sex" or not. Assuming that the sex mix of neighbors' children ("neighbors' children sex mix") influences a woman'sparticipation only through its impact on neighbors' own participation, this result suggests a significant causal effect of neighbors' participation on a woman's participation. Using neighbors' children sex mix as an instrumental variable (IV), our estimates confirm that neighbors' labor market participation has a positive and significant effect on a mother's participation, even though the precise size of this social effect is difficult to evaluate.

\footnotetext{
${ }^{1}$ In his survey, Steven N. Durlauf (2004) provides a description of a selection of 25 recent studies on neighborhood effects and none is about women's participation in the labor market. See also the multidisciplinary survey by Robert Dietz (2001) and the Canadian survey by Philip Oreopoulos (2005). There exists a small literature on the effect of social interactions on the number of hours worked by men (Andrew Grodner and Thomas J. Kniesner 2006).

${ }^{2}$ LFS conducted in Canada and the US also use cluster sampling but only sample about five households within a given area. This small difference makes it basically impossible to use the kind of research strategies we are developing in this paper.
} 
These IV estimates rely on the assumption that neighbors' children sex mix affects a mother's behavior only insofar as it influences neighbors' own behavior. The reform of family benefits that took place in France in 1994 provides us with a way to test this assumption. Before the reform, benefits were given to families with three children or more. After the reform, the eligibility was extended to two-child families. The consequence of this reform was not only a decline in the labor market participation of these families, but also a sharp decline in the influence of their children sex mix on their participation decision. Most interestingly, we find that the influence of neighbors' children sex mix also declined (and became nonsignificant) after the reform. Put differently, neighbors' children sex mix has an effect on a mother's behavior when, and only when, it has an effect on neighbors' own behavior. This finding is obviously consistent with the assumption that neighbors' children sex mix has an effect on a mother's behavior only insofar as it influences their own behavior.

To further explore the robustness of our results, we compare our "sex-mix" estimates to estimates produced using child quarter of birth as a source of identification. Mothers whose children were born at the end of the year participate less in the labor market than other mothers, plausibly because their children have to wait longer to start school and also because their children often adapt to primary school less well than other children. This effect was identified by Jonah B. Gelbach (2002) in the United States, and we find a similar relationship in the French context. In contrast, we find no perceptible effect of child quarter of birth on residential choices. Given these facts, the variation in the proportion of children born at the end of the year across neighborhoods can be used in exactly the same way as the variation in the proportion of "same-sex" families to identify the endogenous social effect on mothers' labor market participation. Most interestingly, the quarter-of-birth instrument provides us with similar estimates of the endogenous social effect as the sex-mix instrument. Overall, our evaluations suggest that a 10 percentage point increase in labor market participation among neighbors generates an increase of about 6 percentage points in a mother's probability of participation.

The paper is organized as follows. The next section provides a short discussion of related literature, and Section II describes the data. Section III shows the influence of the sex of the two eldest siblings on the labor market participation of French mothers. Section IV provides several pieces of evidence suggesting that the sex of the two eldest siblings does not influence neighborhood choice. Section V estimates the (strong) influence of her neighbors' labor market participation on a mother's probability of participation, using the sex of the two eldest siblings of neighbors as an instrumental variable. Also, we compare the estimates obtained with the sexmix instrument with those obtained with the quarter-of-birth instrument. Section VI concludes.

\section{Related Literature}

This paper belongs to the literature which tries to clarify the contribution of social interactions on women's increased involvement in modern economies. We are not aware of studies analyzing the influence of close neighbors on women's labor market 
decisions. Existing studies have largely focused on social interactions between members of the same (broadly defined) family. For example, Raquel Fernandez, Alessandra Fogli, and Claudia Olivetti (2004) make use of the difference across US states of the impact of WWII on mothers' participation to show that a man who is brought up by a working mother is more likely to be married to a woman who works. The authors build on this result to argue that a determinant of the increase in women's involvement in the labor market has been the increasing number of men who, over time, grew up with a different family model. In a related paper, David Neumark and Andrew Postlewaite (1998) suggest that women's decision to participate in the labor market is influenced by the decision of their sisters and by the social status of their sisters-in-law (see also Daniela Del Boca, Marinella Locatelli, and Silvia Pasqua 2000). Isolde Woittiez and Arie Kapteyn (1998) analyze the labor supply behavior of married women using a survey in which questions where asked about the age and education of the people frequently met by the respondents. They show a correlation between a married woman's labor supply behavior and the number of hours worked by the females who have the education and age indicated by the woman as typical of her social environment.

Interesting results are also provided by the Moving to Opportunity (MTO) program. The MTO demonstration provides housing vouchers to a randomly selected group of poor families in five American cities. Available evaluations suggest that the program has significant effects on children's outcomes, but the effects on adults' behavior are more mixed (see, e.g., John Goering, Judith D. Feins, and Todd M. Richardson 2002). The change in neighbors' labor force participation in MTO may have been too small to have generated a detectable effect on women's labor market participation through the peer mechanism studied in this paper.

At a more general level, Claudia Goldin (2006) describes how each generation of women has been influenced by its immediate predecessors and how this process progressively altered the identity of women and shifted it from a family centered world to a more career oriented one. Goldin and Lawrence F. Katz (2002) show that the extremely large effect of the pill on women's educational and occupational choices cannot be fully understood without taking social interactions into account. They argue that when a woman decides to delay marriage, her potential spouses remain in the marriage market longer and, consequently, remain available to other women. Hence, any exogenous shock delaying one woman's marriage (such as pill availability) diminishes the cost for other women of delaying their own marriage and this creates social multiplier effects.

Our study can also be seen as a contribution to the literature analyzing the variation in labor market outcomes across areas or across subgroups of workers within areas. Alesina, Glaeser, and Sacerdote (2005) argue that part of the very strong difference in labor market outcomes between the United States and Europe is due to positive complementarities across people in the enjoyment of leisure time. They provide several pieces of evidence which support the assumption that one person's leisure increases the returns to other people's leisure. One such piece of evidence is the strong convergence to a common two day weekend (i.e., Saturday and Sunday) despite the many disadvantages of crowding infrastructure usage during five days and leaving this infrastructure underutilized during two other days. 


\section{Data Description}

The data used in this paper come from 12 French Labor Force Surveys (LFS) conducted each year between 1990 and 2001 by the French Statistical Office (INSEE). The annual LFS is a large sample representative of the French population aged 15 or older (n 5 150,000, sampling rate 5 1/300). For each respondent, we have standard information on his date of birth, sex, family situation, place of birth, education, and labor market participation (employed versus unemployed). Also, for each household, we know the number, sex, and birth date of the children living in the home. In the remainder, we will focus on the sample of mothers aged 21 to 35, living in two-parent families and having at least two children at the time of the survey $(n 531,311)$. As with Angrist and Evans (1998), we only have information on children still living with their parents. Focusing on mothers who are less than 36 years old prevents us from underestimating women's total number of children and from introducing errors on the rank of the children in the family. Women who are more than 35 years old possibly have adult children, i.e., children who have a higher probability of having left the parental home. Another interest of concentrating on 21-35 year old mothers is that our analysis of the links between the sex of the two eldest siblings and individual labor supply (first stage) will be directly comparable to Angrist and Evans' (1998) analysis on American data.

One key feature of the French LFS is that the basic sampling units actually consist of groups of about 20 adjacent households. ${ }^{3}$ (these groups are called aires). More specifically, a typical LFS consists of a representative sample of about 3,500 aires. Each year, within each aire, all the households are surveyed and, within each household, all the persons aged 15 years old or older are surveyed. The French statistical office (INSEE) has chosen this sampling strategy in order to reduce the travelling expenses of the investigators who are in charge of the survey.

For each woman in our sample, we observe, on average, four other women with two or more children living in the same small neighborhood. ${ }^{4}$ Hence, for each woman in our sample, we can compute several variables describing the average characteristics of the other families with two or more children living in her aire, namely the proportion of families in which the two eldest children are "same sex," the proportion of families whose second child was born at the end of the year, and the proportion of families where the mother participates in the labor market. Let us emphasize that, for each respondent, the different aire-level indicators are constructed using only the information on the neighbors, i.e., the respondent himself is excluded from these indicators.

As far as we know, there is very little empirical evidence on the influence of neighbors on a mother's labor market participation. One issue is that neighborhoods measured in available datasets are often considerably larger than those which matter for outcomes (i.e., close neighborhoods). In the early 1980s, the French Statistical Office has carried out an interesting sociological survey on the intensity of social

\footnotetext{
${ }^{3}$ This is also a feature of the panel Survey on Income Dynamics (PSID). See Gary Solon, Marianne E. Page, and Greg J. Duncan (2000). The sample of the PSID is much smaller than the LFS sample, however.

${ }^{4}$ About 16 percent of mothers in our sample have one such neighbor only, 17 percent have two, 15 percent have three, 13 percent have four, 10 percent have five, and about 30 percent have 6 or more.
} 
interactions within neighborhoods (François Héran 1986). It shows that most French people define as "neighbors" persons who are living in their very close neighborhood only, i.e., in the same building or adjacent houses. Also, it shows that a very large proportion of French people (about 91 percent) actually interact with their "neighbors." Interestingly enough, the survey used in this paper enables us to identify the influence of these social interactions. The sampling unit consists of small groups of about 20 to 30 adjacent houses. It provides us with a large sample of mothers with detailed information on the situation of all the other mothers living in their close neighborhood. It makes it possible to analyze how mothers living in adjacent houses actually influence each other. ${ }^{5}$ It would not have been possible if we had been obliged to proxy neighborhoods with larger groups of people such as census tracts (i.e., several thousands of individuals). Also, according to Héran (1986), the relationships with neighbors are maintained mostly by women and especially women with children. What emerges from Héran's study is that mothers are actually much more exposed than others to the effect of neighborhood interactions. The results of this study back up our choice of focusing on women with children.

\section{Sex of Eldest Siblings, Fertility, and Labor Market Participation}

Table 1 analyzes the labor market participation of mothers according to their children sex mix. It shows that the probability of labor market participation is about 1.7 percentage points lower among mothers with "same-sex" siblings than among the other mothers. This difference is perceptible regardless of whether the first born child is a boy or a girl, even if it is more significant (2.4 points) when it is a boy. Mothers' participation is not as well measured in the general census of the population as in the LFS. However, we have checked that the last census of the population (carried out in 1999) provides the same result, that mothers whose eldest children are "same sex" participate in the labor market significantly less than others, the difference being a little more than 1.1 points in the census. Angrist and Evans (1998) find the same result in the United States, even though the effect is not as strong in the United States as in France.

There are several potential explanations for this relationship between children sex mix and the labor market participation of mothers (Mark R. Rosenzweig and Kenneth I. Wolpin 2000). Same sex children may be less costly to rear and having "same-sex" children may make it less urgent for a mother to work (direct effect). The most plausible explanation is indirect, however. Children sex mix influences the participation of mothers because it affects the final number of children in the family. French and American mothers with two girls or two boys are more likely to have a third child than mothers who already have a boy and a girl (Angrist and Evans 1998 and Goux and Maurin 2005). Table 1 confirms that the proportion of

\footnotetext{
${ }^{5}$ There exists a related literature which studies interactions among close neighbors, even though the focus is not on the labor market participation of women (see e.g., Yannis M. Ioannides 2002; Ioannides 2003; Ionnadies and Jeffrey E. Zabel 2003; Anne C. Case and Katz 1991; and Solon, Page, and Duncan 2000). Also Dominique Goux and Maurin (2007) use French Labor Force surveys to evaluate the effect of close neighbors on adolescents' educational outcomes.
} 
Table 1-Impact of the Sex Composition of the Two Eldest Children on Mothers' Fertility and Labor Market Participation

\begin{tabular}{|c|c|c|c|c|c|c|c|}
\hline & \multicolumn{7}{|c|}{ Sex of the two eldest children } \\
\hline & $\begin{array}{l}2 \text { boys } \\
\text { (1) }\end{array}$ & $\begin{array}{l}2 \text { girls } \\
\text { (2) }\end{array}$ & $\begin{array}{l}\text { boy, girl } \\
\text { (3) }\end{array}$ & $\begin{array}{l}\text { girl, boy } \\
\text { (4) }\end{array}$ & $\begin{array}{l}\text { Same sex } \\
\text { (5) }\end{array}$ & $\begin{array}{l}\text { Different } \\
\text { sex } \\
(6)\end{array}$ & $\begin{array}{l}\text { difference } \\
\text { (5) } 2(6)\end{array}$ \\
\hline $\begin{array}{l}\text { Proportion in } \\
\text { population }\end{array}$ & $\begin{array}{c}0.262 \\
(0.002)\end{array}$ & $\begin{array}{c}0.240 \\
(0.002)\end{array}$ & $\begin{array}{c}0.250 \\
(0.002)\end{array}$ & $\begin{array}{c}0.247 \\
(0.002)\end{array}$ & $\begin{array}{c}0.503 \\
(0.002)\end{array}$ & $\begin{array}{c}0.497 \\
(0.002)\end{array}$ & $\begin{array}{c}0.006 \\
(0.003)\end{array}$ \\
\hline $\begin{array}{l}\text { Proportion } \\
3 \text { children or more }\end{array}$ & $\begin{array}{c}0.313 \\
(0.005)\end{array}$ & $\begin{array}{c}0.313 \\
(0.005)\end{array}$ & $\begin{array}{c}0.270 \\
(0.005)\end{array}$ & $\begin{array}{c}0.280 \\
(0.005)\end{array}$ & $\begin{array}{c}0.313 \\
(0.004)\end{array}$ & $\begin{array}{c}0.275 \\
(0.004)\end{array}$ & $\begin{array}{l}0.038 * \\
(0.005)\end{array}$ \\
\hline $\begin{array}{l}\text { Proportion } \\
\text { participating in } \\
\text { labor market }\end{array}$ & $\begin{array}{c}0.585 \\
(0.006)\end{array}$ & $\begin{array}{c}0.593 \\
(0.006)\end{array}$ & $\begin{array}{c}0.609 \\
(0.006)\end{array}$ & $\begin{array}{c}0.602 \\
(0.006)\end{array}$ & $\begin{array}{c}0.589 \\
(0.004)\end{array}$ & $\begin{array}{c}0.605 \\
(0.004)\end{array}$ & $\begin{array}{c}20.017^{*} \\
(0.006)\end{array}$ \\
\hline
\end{tabular}

notes: Sample: Women aged 21235 years old, two children or more ( $n$ 5 31,311). Standard errors are in parentheses and * denotes significance at the 95 percent confidence level.

Source: LFS 199022001, Insee.

French families with at least three children is about 4 points higher in families where the eldest siblings are "same sex" (31.3 percent) than in families where the eldest siblings are "different sex" (27.5 percent). These differences in the final number of children cannot be explained by differences in the standard individual determinants of fertility. There is no significant difference in age, education level, nationality, or in birth timing between mothers according to their children sex mix (see Table 2, panel A). Also, when we regress the probability of having a third child or the probability of labor market participation on the sex composition of the two eldest siblings, the estimated effects are almost exactly the same regardless of whether we use a detailed set of sociodemographic control variables or not (not reported). These results confirm that the relationships between children sex mix and mothers' outcomes are not due to variation in the sociodemographic characteristics of mothers according to the sex of their eldest children. What is at stake here really seems to be a preference of parents for mixed-sex siblings and it is this preference that influences mothers' participation decisions.

These findings are consistent with the literature, and notably with the seminal results of Angrist and Evans (1998). Children sex mix affects the total number of children, but also the labor market participation of mothers. The magnitude of the effect of children's sex on fertility and participation is different in their study on American data than in our French study, however, even though the method and the samples are defined the same way. The sex of the two eldest siblings have a smaller impact on fertility in France than in the United States (about 6 points in the United States versus 4 points here), but a higher impact on mothers' participation (20.5 points in the United States versus 21.7 in France).

Assuming that children sex mix affects the participation of mothers only because it influences the total number of children, the ratio between the impact of children sex mix on participation and its impact on fertility provides us with an estimate of the causal effect of having a third child on the mothers' probability of participating in the labor market. This Wald estimate (about 20.4) suggests a higher elasticity in France than that estimated by Angrist and Evans (1998) in the United States 
Table 2-Demographic Characteristics of Mothers According to the Sex Composition and the Quarter of Birth of the Two Eldest Siblings

\begin{tabular}{|c|c|c|c|c|c|}
\hline & \multicolumn{5}{|c|}{ Mothers' characteristics } \\
\hline & $\begin{array}{l}\text { Age } \\
(1)\end{array}$ & $\begin{array}{c}\text { Age at } \\
\text { 1st birth } \\
\text { (2) }\end{array}$ & $\begin{array}{l}\text { French } \\
\text { (3) }\end{array}$ & $\begin{array}{l}\text { Number of children } \\
\text { (4) }\end{array}$ & $\begin{array}{l}\text { High school } \\
\text { graduate } \\
\text { (5) }\end{array}$ \\
\hline \multicolumn{6}{|l|}{ panel $A$} \\
\hline (a) Same sex & $\begin{array}{l}31.04 \\
(0.02)\end{array}$ & $\begin{array}{c}22.92 \\
(0.03)\end{array}$ & $\begin{array}{c}0.910 \\
(0.002)\end{array}$ & $\begin{array}{c}2.420 \\
(0.006)\end{array}$ & $\begin{array}{c}0.711 \\
(0.004)\end{array}$ \\
\hline (b) Different sex & $\begin{array}{l}31.03 \\
(0.02)\end{array}$ & $\begin{array}{l}22.91 \\
(0.03)\end{array}$ & $\begin{array}{c}0.913 \\
(0.002)\end{array}$ & $\begin{array}{c}2.364 \\
(0.006)\end{array}$ & $\begin{array}{c}0.712 \\
(0.004)\end{array}$ \\
\hline difference(a)2(b) & $\begin{array}{c}0.01 \\
(0.04)\end{array}$ & $\begin{array}{c}0.01 \\
(0.04)\end{array}$ & $\begin{array}{r}20.003 \\
(0.003)\end{array}$ & $\begin{array}{c}0.056^{*} \\
(0.008)\end{array}$ & $\begin{array}{r}20.001 \\
(0.005)\end{array}$ \\
\hline \multicolumn{6}{|l|}{ panel $B$} \\
\hline (c) 2nd birth last quarter & $\begin{array}{l}30.99 \\
(0.04)\end{array}$ & $\begin{array}{l}22.98 \\
(0.04)\end{array}$ & $\begin{array}{c}0.912 \\
(0.003)\end{array}$ & $\begin{array}{c}2.389 \\
(0.008)\end{array}$ & $\begin{array}{c}0.710 \\
(0.006)\end{array}$ \\
\hline (d) 2nd birth in quarter 123 & $\begin{array}{l}31.06 \\
(0.02)\end{array}$ & $\begin{array}{c}22.90 \\
(0.02)\end{array}$ & $\begin{array}{c}0.911 \\
(0.002)\end{array}$ & $\begin{array}{c}2.393 \\
(0.005)\end{array}$ & $\begin{array}{c}0.712 \\
(0.003)\end{array}$ \\
\hline difference $(c) 2(d)$ & $\begin{array}{r}20.070 \\
(0.041)\end{array}$ & $\begin{array}{c}0.079 \\
(0.044)\end{array}$ & $\begin{array}{c}0.001 \\
(0.004)\end{array}$ & $\begin{array}{r}20.005 \\
(0.009)\end{array}$ & $\begin{array}{r}20.002 \\
(0.006)\end{array}$ \\
\hline
\end{tabular}

notes: Sample: Women aged 21235 years old with two children or more ( $n 5$ 31,311). The average number of children of mothers with "same sex" eldest siblings is 2.420 , whereas the average number of children of mothers with different sex eldest siblings is 2.364. Standard errors are in parentheses and * denotes significance at the 95 percent confidence level.

Source: LFS 199022001, Insee.

(about 20.1). Having more than two children seems to have a more negative impact on mothers' participation in France than in the United States. This difference has plausibly deep institutional causes for which analysis would exceed the scope of this paper. For now, it is enough to emphasize that the children sex mix influences the participation of French mothers more than American ones, and that this is probably because the effect of the number of children on mothers' participation is more negative in France than in the United States.

\section{Sex of Eldest Siblings and Neighborhood Choice}

The children sex mix affects the decision of having a third child, which in turn may entail a residential change. Hence, we cannot exclude that the children sex mix also determines (indirectly) the neighborhood in which mothers bring up their children and make their labor market decisions.

If this was the case, the children sex mix of a family would be correlated with the children sex mix of other families in the neighborhood and families with "samesex" eldest children would not be randomly distributed across neighborhoods. They would be concentrated in some specific neighborhoods. To test this assumption we have compared the actual distribution of the number of families with "same-sex" eldest children across neighborhoods with the distribution that would be observed 
Table 3-The Distribution of Neighborhoods According to the Number of Mothers with "Same-Sex" Eldest Siblings and its Distance to Random Assignment

\begin{tabular}{|c|c|c|c|}
\hline \multirow[b]{2}{*}{$\begin{array}{l}\text { Number of mothers with } \\
\text { "same-sex" eldest } \\
\text { siblings }\end{array}$} & \multicolumn{3}{|c|}{$\begin{array}{l}\text { Distribution of neighborhoods according to the number of } \\
\text { mothers with "same-sex" eldest siblings }\end{array}$} \\
\hline & $\begin{array}{c}\text { Observed distribution of } \\
\text { neighborhoods } \\
\text { (p, in percent) } \\
(1)\end{array}$ & $\begin{array}{l}\text { Distribution under random } \\
\text { assignment assumption } \\
\left(p_{0} \text {, in percent }\right) \\
(2)\end{array}$ & $n\left(p 2 p_{0}\right)^{2} / p_{0}$ \\
\hline 0 & 11.80 & 11.99 & 0.23 \\
\hline 1 & 31.15 & 30.61 & 0.53 \\
\hline 2 & 28.03 & 28.31 & 0.21 \\
\hline 3 & 14.36 & 14.48 & 0.08 \\
\hline 4 & 7.41 & 7.14 & 0.78 \\
\hline 5 & 3.53 & 3.47 & 0.08 \\
\hline 61 & 3.72 & 4.00 & 1.50 \\
\hline $\begin{array}{l}\mathrm{x}^{2} \text { stat. } \\
\quad(p \text {-value })\end{array}$ & - & - & $\begin{array}{c}3.41 \\
(0.76)\end{array}$ \\
\hline
\end{tabular}

notes: Sample: Women aged 21-35 years old with two children or more (n 5 31,311). The observed proportion of neighborhoods without any "same-sex" families is 0.1180 . The proportion would be 0.1199 if "same-sex" families were randomly assigned across neighborhoods. A chi-squared test does not reject the random assignment assumption.

Source: LFS 1990-2001, Insee.

if these families were randomly assigned across neighborhoods. ${ }^{6}$ The two distributions are actually almost identical (see Table 3). A chi-squared test does not reject the random assignment assumption at standard level. The distribution of families with "same-sex" eldest children is actually not distinguishable from random assignment even when we make the comparison conditional on the total number of families living in the neighborhood. This analysis is available upon request.

Overall, our data do not reveal any significant residential concentration of families with "same-sex" eldest children. Further exploration of the data confirms that there is no correlation between a mother's children sex mix and the demographic characteristics of the other mothers living in the same neighborhood. Specifically, there is no correlation between a mother's children sex mix and the age, education, or nationality of the other mothers living in the same neighborhood (see Table 4, panel A). Also, a mother's children sex mix is not correlated with the number of children of the other families in the neighborhood. The average number of children of neighbors is exactly the same when own eldest children are "same sex" as when they are not "same sex."

\section{Sex of Eldest Siblings and Neighbors' Behavior}

A woman's children sex mix is a determining factor of her labor market participation. On the other hand, the distribution of families with "same-sex" eldest

\footnotetext{
${ }^{6}$ Under the random assignment assumption, the probability of observing $k$ same-sex families in a neighborhood of size $n$ is simply $c(n, k) p^{k}\left(\begin{array}{lll}1 & 2 p\end{array}\right)^{n 2 k}$ where $p$ denotes the proportion of same-sex families in the population.
} 
Table 4-The Sex Composition of Own Eldest Siblings and the Demographic Characteristics of the Other Mothers Living in the Same Neighborhood

\begin{tabular}{|c|c|c|c|c|c|c|}
\hline & \multicolumn{6}{|c|}{ Characteristics of the other mothers in the neighborhood } \\
\hline & $\begin{array}{l}\text { Age } \\
(1)\end{array}$ & $\begin{array}{l}\text { Age at } \\
\text { 1st birth } \\
\text { (2) }\end{array}$ & $\begin{array}{l}\text { French } \\
\text { (3) }\end{array}$ & $\begin{array}{l}\text { Number of } \\
\text { children } \\
\text { (4) }\end{array}$ & $\begin{array}{l}\text { High school } \\
\text { graduate } \\
\text { (5) }\end{array}$ & $\begin{array}{l}\text { LM Part. } \\
\qquad(6)\end{array}$ \\
\hline \multicolumn{7}{|c|}{ panel A: own children sex-mix } \\
\hline (a) Same sex & $\begin{array}{l}31.04 \\
(0.02)\end{array}$ & $\begin{array}{c}22.92 \\
(0.02)\end{array}$ & $\begin{array}{c}0.911 \\
(0.002)\end{array}$ & $\begin{array}{l}2.391 \\
(0.004)\end{array}$ & $\begin{array}{c}0.712 \\
(0.003)\end{array}$ & $\begin{array}{c}0.594 \\
(0.003)\end{array}$ \\
\hline (b) Different sex & $\begin{array}{l}31.04 \\
(0.02)\end{array}$ & $\begin{array}{c}22.92 \\
(0.02)\end{array}$ & $\begin{array}{c}0.912 \\
(0.002)\end{array}$ & $\begin{array}{l}2.393 \\
(0.004)\end{array}$ & $\begin{array}{c}0.711 \\
(0.003)\end{array}$ & $\begin{array}{c}0.600 \\
(0.003)\end{array}$ \\
\hline \multirow[t]{4}{*}{$\begin{array}{l}\text { difference } \\
\text { (a) } 2 \text { (b) }\end{array}$} & $\begin{array}{c}20.00 \\
(0.02)\end{array}$ & $\begin{array}{r}20.00 \\
(0.04)\end{array}$ & $\begin{array}{c}20.001 \\
(0.002)\end{array}$ & $\begin{array}{c}20.002 \\
(0.005)\end{array}$ & $\begin{array}{c}0.000 \\
(0.004)\end{array}$ & $\begin{array}{c}20.006 \\
(0.004)\end{array}$ \\
\hline & \multicolumn{6}{|c|}{ Individual characteristics of mothers } \\
\hline & Age & $\begin{array}{l}\text { Age at } \\
\text { 1st birth }\end{array}$ & French & $\begin{array}{c}\text { Number of } \\
\text { children }\end{array}$ & $\begin{array}{c}\text { High school } \\
\text { graduate }\end{array}$ & LM Part. \\
\hline & (1) & $(2)$ & (3) & (4) & (5) & (6) \\
\hline $\begin{array}{l}\text { panel B: neighbors' } \\
\text { (c) Proportion } \\
\text { samesex - } 0.75\end{array}$ & $\begin{array}{l}\text { ildren sex-mix } \\
31.14 \\
(0.04)\end{array}$ & $\begin{array}{l}23.11 \\
(0.05)\end{array}$ & $\begin{array}{c}0.906 \\
(0.003)\end{array}$ & $\begin{array}{l}2.373 \\
(0.009)\end{array}$ & $\begin{array}{c}0.681 \\
(0.006)\end{array}$ & $\begin{array}{c}0.591 \\
(0.006)\end{array}$ \\
\hline $\begin{array}{l}\text { (d) Proportion } \\
\text { samesex , } 0.25\end{array}$ & $\begin{array}{l}31.15 \\
(0.04)\end{array}$ & $\begin{array}{l}23.04 \\
(0.05)\end{array}$ & $\begin{array}{c}0.908 \\
(0.003)\end{array}$ & $\begin{array}{l}2.378 \\
(0.009)\end{array}$ & $\begin{array}{c}0.685 \\
(0.006)\end{array}$ & $\begin{array}{c}0.611 \\
(0.006)\end{array}$ \\
\hline $\begin{array}{l}\text { difference } \\
\text { (c) } 2 \text { (d) }\end{array}$ & $\begin{array}{c}0.00 \\
(0.06)\end{array}$ & $\begin{array}{c}0.07 \\
(0.06)\end{array}$ & $\begin{array}{c}20.002 \\
(0.005)\end{array}$ & $\begin{array}{c}20.006 \\
(0.013)\end{array}$ & $\begin{array}{c}20.004 \\
(0.009)\end{array}$ & $\begin{array}{c}20.020 * \\
(0.009)\end{array}$ \\
\hline
\end{tabular}

notes: Sample: Women aged 21-35 years old with two children or more ( $n$ 5 31,311). Panel B compares the characteristics of mothers with respect to the proportion of neighbors with same-sex eldest siblings. When the proportion is larger than 0.75 (which corresponds to the top quartile of the distribution of this proportion), the labor market participation rate is 59.1. When the proportion is smaller than 0.25 (bottom quartile) the participation rate is 61.1. Standard errors are in parentheses.

* Significance at the 95 percent confidence level.

Source: LFS 1990-2001, Insee.

children across neighborhoods is not distinguishable from random assignment. In other words, the variation across neighborhoods in the proportion of families with "same-sex" eldest children is similar to a random shock to neighbors' participation. Given this fact, the next important issue is whether this proportion has an influence on a mother's labor market participation.

Interestingly enough, Table 4, panel B reveals that this is the case. A mother with a relatively high proportion of "same-sex" families in her neighborhood" has on average the same education, age, number of children, or nationality as a mother with a relatively low proportion of such neighbors. The only significant difference is that she

\footnotetext{
${ }^{7}$ A quarter of our sample of mothers is such that the proportion of neighbors with "same-sex" eldest children is larger than 75 percent. A quarter is such that the proportion of neighbors with "same-sex" eldest children is smaller than 25 percent. Table 4 shows the difference in behaviors and characteristics between these two quartiles of the distribution of the proportion of "same-sex" neighbors.
} 
participates less in the labor market (about -2 percentage point). There is obviously a strong case for the existence of contextual effects on participation decisions.

To further explore the nature of these effects, it is possible to look at more and less educated mothers separately. The effect of having "same-sex" eldest siblings on a mother's labor market participation is indeed significant only for less educated mothers (see Table 5, panel A). The influence is negligible for more educated mothers. ${ }^{8}$ Within this context, the question is whether the influence of the sex of neighbors' eldest children on a mother's labor market participation depends on neighbors' education. panel B of Table 5 shows that this is the case. When we focus on the subsample of mothers with educated neighbors only, we do not find any significant effect of neighbors' children sex mix on a mother's labor market participation. In contrast, when we focus on the subsample of mothers with some less educated neighbors, the effect of having "same-sex" neighbors becomes negative and significant. Overall, neighbors' children sex mix has a significant effect on a mother's behavior when, and only when, it affects neighbors' own behavior (i.e., the noneducated case). This set of findings is consistent with the assumption that neighbors' children sex mix affects a mother's behavior only insofar as it affects neighbors' behavior.

In addition, we have checked that there is no significant difference in the labor market participation of fathers, nor in the labor market participation of women without children, with respect to the children sex mix of the other mothers living in the same neighborhood (not reported). This result further confirms that a mother's behavior is influenced by neighbors' children sex mix not because of correlated neighborhood effects, but because of social interactions that take place between families.

\section{A. Lessons from the 1994 reform in Family Benefits}

The 1994 reform of family benefits provides us with another interesting source of identification. Before July 1994, French mothers with three or more children were eligible to receive a 450 euros monthly benefit (allocation parentale d'éducation, hereafter, APE), about half the minimum wage, provided that they did not participate in the labor market and at least one of their children had not yet reached the age of three. After July 1994, French mothers became eligible for this benefit after the birth of their second child. In other words, mothers whose second child was born after July 1994 were eligible to the benefit after the second birth whereas women whose second child was born before July 1994 were eligible to the $A p E$ benefit after the third birth only. ${ }^{9}$

\footnotetext{
${ }^{8}$ Also, we have checked that the influence of the sex composition of the eldest children on family size is significant for less educated mothers only. These results are consistent with standard labor supply models where the participation in the labor market depends on whether mothers' potential wage is larger or not than the marginal utility of substituting "time spent at work" for "time spent with children" and where this marginal utility decreases when the eldest siblings are "same sex." In such a case, mothers whose potential wages are sufficiently large do participate in the labor market regardless of the sex of their eldest siblings, and the instrument has an effect on low potential wage persons only.

${ }^{9}$ Thomas Piketty (2005) has explored the effect of this reform on women's fertility and participation in the labor market.
} 
Table 5-The Sex Composition of the Two Eldest Siblings and Mothers' Labor Market Participation, by Education Groups and by Reform Status

\begin{tabular}{|c|c|c|}
\hline & High school dropouts & High school graduates \\
\hline \multicolumn{3}{|l|}{ panel A: own children sex mix } \\
\hline (a) Same sex & $\begin{array}{c}0.528 \\
(0.005)\end{array}$ & $\begin{array}{c}0.739 \\
(0.007)\end{array}$ \\
\hline (b) Different sex & $\begin{array}{c}0.554 \\
(0.005)\end{array}$ & $\begin{array}{c}0.734 \\
(0.007)\end{array}$ \\
\hline difference $(a) 2(b)$ & $\begin{array}{c}20.026^{*} \\
(0.007)\end{array}$ & $\begin{array}{c}0.005 \\
(0.009)\end{array}$ \\
\hline \multirow[t]{2}{*}{ Observations } & 22,275 & 9,036 \\
\hline & $\begin{array}{l}\text { Some high school } \\
\text { dropouts in the neighborhood }\end{array}$ & $\begin{array}{l}\text { No high school dropouts in } \\
\text { the neighborhood }\end{array}$ \\
\hline $\begin{array}{l}\text { panel B: neighbors' children sex mix } \\
\text { (c) Prop. same sex - } 0.75\end{array}$ & $\begin{array}{c}0.580 \\
(0.006)\end{array}$ & $\begin{array}{c}0.646 \\
(0.015)\end{array}$ \\
\hline (d) Prop. same sex , 0.25 & $\begin{array}{c}0.607 \\
(0.007)\end{array}$ & $\begin{array}{c}0.627 \\
(0.015)\end{array}$ \\
\hline difference $(c) 2(d)$ & $\begin{array}{c}20.028 * \\
(0.010)\end{array}$ & $\begin{array}{c}0.018 \\
(0.022)\end{array}$ \\
\hline \multirow[t]{2}{*}{ Observations } & 28,852 & 2,459 \\
\hline & Prereform mothers & Post-reform mothers \\
\hline $\begin{array}{l}\text { panel c: own children sex mix } \\
\text { (e) Same sex }\end{array}$ & $\begin{array}{c}0.598 \\
(0.004)\end{array}$ & $\begin{array}{c}0.559 \\
(0.008)\end{array}$ \\
\hline (f) Different sex & $\begin{array}{c}0.622 \\
(0.004)\end{array}$ & $\begin{array}{c}0.554 \\
(0.008)\end{array}$ \\
\hline difference $(e) 2(f)$ & $\begin{array}{c}20.024 * \\
(0.006)\end{array}$ & $\begin{array}{c}0.005 \\
(0.011)\end{array}$ \\
\hline \multirow[t]{2}{*}{ Observations } & 23,580 & 7,731 \\
\hline & $\begin{array}{l}\text { Some prereform mothers } \\
\text { in the neighborhood }\end{array}$ & $\begin{array}{l}\text { No prereform mothers } \\
\text { in the neighborhood }\end{array}$ \\
\hline $\begin{array}{l}\text { panel d: neighbors' children sex mix } \\
\text { (g) Prop. same sex - } 0.75\end{array}$ & $\begin{array}{c}0.587 \\
(0.006)\end{array}$ & $\begin{array}{c}0.607 \\
(0.015)\end{array}$ \\
\hline (h) Prop. same sex > 0.25 & $\begin{array}{c}0.612 \\
(0.007)\end{array}$ & $\begin{array}{c}0.606 \\
(0.015)\end{array}$ \\
\hline difference $(g) 2(h)$ & $\begin{array}{c}20.025^{*} \\
(0.010)\end{array}$ & $\begin{array}{c}0.001 \\
(0.021)\end{array}$ \\
\hline Observations & 28,013 & 3,298 \\
\hline
\end{tabular}

notes: Sample: Women aged 21-35 years old with two children or more. Column (2) of panel A analyzes mothers who are high school graduates. The proportion participating in the labor market is 0.739 when their eldest children are "same sex." The second column of panel B analyzes the behavior of mothers whose neighbors are all high school graduates. The proportion participating in the labor market is 0.646 when the proportion of neighbors with same-sex eldest siblings is larger than 0.75 . Standard errors are in parentheses.

* Significant at the 95 percent confidence level.

Source: LFS 199022001, Insee. 
By construction, this reform has increased the potential wage above which labor market participation becomes profitable and above which the children sex mix may have an effect on participation decisions. In other words, the reform has modified the group of mothers potentially affected by the "same-sex" instrument (i.e., they have higher potential wages), and it is not clear whether the effect of the instrument is as strong on the post-reform marginal group as on the prereform one. To address this issue, we have compared mothers whose second child was born before July 1994 with those whose second child was born after July 1994 (see Table 5, panel C). Most interestingly, it reveals that the effect of having "same-sex" eldest children is large and significant before the reform only. The influence becomes negligible and statistically nonsignificant after the reform. ${ }^{10}$

Given this fact, the question is whether the influence of neighbors' children sex mix decreases after the reform. panel D of Table 5 shows this is the case. A significant negative effect of neighbors' children sex mix is perceptible only when we focus on mothers with "prereform" neighbors. In contrast, when we focus on mothers with "post-reform" neighbors only, the effect of the sex composition of neighbors' eldest children on mothers' participation becomes negligible. In other words, neighbors' children sex mix has a significant impact on a mother's labor market participation when, and only when, it affects neighbors' own labor market participation.

\section{B. An Evaluation of the Endogenous Social Effect}

The change in the effect of neighbors' children sex mix on a mother's labor market participation after the 1994 reform suggests that this variable has an influence only insofar as it affects neighbors' labor market participation. Under this assumption, it is possible to provide simple estimates of the effect of neighbors' labor market participation on a mother's participation, using the variation in the sex composition of eldest children across neighborhoods as a source of identification. Using the terminology of Manski (1993), the impact of other mothers' labor market participation on a mother's labor market participation corresponds to the endogenous effect. Table 6 shows three different sets of regressions. The first set is estimated on the full sample of mothers and uses the proportion of other mothers with "same-sex" eldest siblings in the neighborhood as an instrument (panel A). The second set of regressions uses the same instrument, but is estimated on the sample of mothers with "prereform" neighbors (panel B). The last set is estimated on the full sample and uses the variation in the proportion of "same-sex" neighbors among prereform neighbors as the sole source of identification (panel C). Note that panels B and C use the same source of identification (i.e., the interaction between the reform and neighbors' children sex mix). Assuming that our identifying assumptions are correct, these specifications should provide us with similar IV results.

\footnotetext{
${ }^{10}$ This finding suggests that the decisions taken by mothers with higher potential wages are less influenced by the sex composition of their siblings than those taken by mothers with lower potential wages. This result is consistent with the lower effect of the sex-mix instrument observed in the more educated group.
} 
Table 6-The Endogenous Social Effect: Evaluations using Neighbors' Children Sex Mix and Prereform Neighbors Children Sex Mix as Instrumental Variables

\begin{tabular}{|c|c|c|c|c|c|}
\hline \multirow[t]{2}{*}{ panel A: (Full sample) } & \multicolumn{4}{|c|}{ Dependent variable: LM participation } & \multirow{2}{*}{$\begin{array}{c}\text { Dependent variable: } \\
3 \text { children or more } \\
\text { (5) }\end{array}$} \\
\hline & $\begin{array}{c}\text { First stage } \\
\text { (1) }\end{array}$ & $\begin{array}{l}\text { Reduced form } \\
\text { (2) }\end{array}$ & $\begin{array}{l}\text { IV } \\
\text { (3) }\end{array}$ & $\begin{array}{l}\text { IV } \\
\text { (4) }\end{array}$ & \\
\hline Proportion participating in the LM & - & - & $\begin{array}{c}0.781 \\
(0.470)\end{array}$ & $\begin{array}{c}0.860 \\
(0.458)\end{array}$ & - \\
\hline Proportion same sex & $\begin{array}{c}20.021^{*} \\
(0.007)\end{array}$ & $\begin{array}{r}20.017 * \\
(0.009)\end{array}$ & - & - & $\begin{array}{c}20.004 \\
(0.008)\end{array}$ \\
\hline 3 children or more & - & - & - & $\begin{array}{r}20.346 * \\
(0.151)\end{array}$ & - \\
\hline
\end{tabular}

panel B: (Some prereform neighbors)

\begin{tabular}{|c|c|c|c|c|c|}
\hline & \multicolumn{4}{|c|}{ Dependent variable: LM participation } & \multirow{2}{*}{$\begin{array}{c}\text { Dependent variable: } \\
3 \text { children or more } \\
\text { (5) }\end{array}$} \\
\hline & $\begin{array}{c}\text { First stage } \\
\text { (1) }\end{array}$ & $\begin{array}{l}\text { Reduced form } \\
\text { (2) }\end{array}$ & $\begin{array}{l}\text { IV } \\
(3)\end{array}$ & $\begin{array}{l}\text { IV } \\
(4)\end{array}$ & \\
\hline Proportion participating in the LM & - & - & $\begin{array}{c}0.613^{*} \\
(0.311)\end{array}$ & $\begin{array}{c}0.685^{*} \\
(0.307)\end{array}$ & - \\
\hline Proportion same sex & $\begin{array}{r}20.034^{*} \\
(0.008)\end{array}$ & $\begin{array}{r}20.021 * \\
(0.010)\end{array}$ & - & - & $\begin{array}{c}0.004 \\
(0.008)\end{array}$ \\
\hline 3 children or more & - & - & - & $\begin{array}{r}20.413^{*} \\
(0.144)\end{array}$ & - \\
\hline
\end{tabular}

panel c: (Full sample)

\begin{tabular}{|c|c|c|c|c|c|}
\hline & \multicolumn{4}{|c|}{ Dependent variable: LM participation } & \multirow{2}{*}{$\begin{array}{c}\text { Dependent variable: } \\
3 \text { children or more } \\
\text { (5) }\end{array}$} \\
\hline & $\begin{array}{c}\text { First stage } \\
\text { (1) }\end{array}$ & $\begin{array}{l}\text { Reduced form } \\
\text { (2) }\end{array}$ & $\begin{array}{l}\text { IV } \\
(3)\end{array}$ & $\begin{array}{l}\text { IV } \\
(4)\end{array}$ & \\
\hline Proportion participating in the LM & - & - & $\begin{array}{c}0.585 * \\
(0.299)\end{array}$ & $\begin{array}{l}0.600^{*} \\
(0.291)\end{array}$ & - \\
\hline Proportion same sex & $\begin{array}{r}20.037 * \\
(0.008)\end{array}$ & $\begin{array}{r}20.022 * \\
(0.010)\end{array}$ & - & - & $\begin{array}{c}0.002 \\
(0.010)\end{array}$ \\
\hline 3 children or more & - & - & - & $\begin{array}{r}20.396 * \\
(0.136)\end{array}$ & - \\
\hline
\end{tabular}

notes: (1) The number of observations is 31,311 for panels A and C and 28,013 for panel B. All regressions include a set of individual control variables: a dummy indicating whether own eldest children are same sex, a dummy indicating whether the second child was born before the reform and an interaction between these two dummies, a dummy indicating high school graduation. Regressions shown in panel C also include the proportion of "postreform" mothers and the proportion of mothers who are both "post-reform" and "same sex" as additional controls. Standard errors (in parentheses) are adjusted for potential serial and spatial correlation at the "aire” level and * denotes significance at the 95 percent confidence level.

The first column of Table 6 shows the results of the first-stage regressions for the three different specifications. ${ }^{11}$ They confirm that neighbors whose eldest children are "same sex" are less likely to participate in the labor market than other neighbors. Also, the regressions confirm that the effect is significant only for neighbors

${ }^{11}$ In computing the standard errors, we allow for arbitrary spatial correlation and for arbitrary serial correlation. 
whose eldest children were born before the 1994 reform. The second column shows the results of the corresponding reduced-form regressions. Does the behavior of a mother vary with the sex of the eldest children of the other mothers living in the same neighborhood? Again, the regression results are consistent with previous statistical analysis. A mother whose neighbors have "same-sex" eldest children is less likely to participate in the labor market than other mothers. Also, the second and third panels confirm that the children of prereform neighbors have a more significant impact than the children of post-reform neighbors. These different results are consistent with our identifying assumption that the sex composition of neighbors' eldest siblings affects a mother's behavior only insofar as it affects neighbors' behavior. Another piece of evidence is provided by the fact that neighbors' children sex mix has no reduced-form effect on the behavior of fathers or on the behavior of women without children (not reported).

The third column of Table 6 shows the results of the corresponding IV regressions. They provide estimates that do not vary significantly across specifications, but become more precise when we use the variations in the proportion of "samesex" families within the set of prereform neighbors as a source of identification. These estimates suggest that a 10 percentage point increase in the proportion of close neighbors participating in the labor market generates a positive and significant increase in the individual probability of labor market participation of about 6 percentage points.

The fourth column of Table 6 shows IV estimates where own fertility is used as an additional explanatory factor. The significant and negative effect of own fertility is identified using own children sex mix as an instrumental variable. Comfortingly, the estimated endogenous social effects remain very similar to those obtained when we do not control for own fertility. ${ }^{12}$ This is a consequence of the fact that neighbors' children sex mix has no effect on a mother's fertility, as confirmed by the last column of Table 6. This finding suggests that neighbors' fertility has, as such, no effect on own fertility.

Table 7 provides a comparison of OLS and IV estimates using the same instrument as in the last panel of Table 6 (i.e., the children sex mix of prereform neighbors). When we work on the full sample, the IV estimate is much larger than the OLS estimate (0.17) even if the difference between the two estimates is not significant. It is something of a puzzle, since endogenous neighborhood selection is typically likely to bias OLS coefficient upward. ${ }^{13}$ One possible explanation is that the aire where a mother lives does not necessarily include all of her "true" neighbors, i.e., all the other mothers living in her close neighborhood and with whom she actually interacts. In other words, the labor market participation of the other mothers living in the same aire provides us with a measure of the labor market participation of "true" neighbors which is plausibly affected by an error. This results in an attenuation bias

\footnotetext{
${ }^{12}$ We have also checked that our results are unchanged when we control for children's age.

${ }^{13}$ Interestingly enough, comparing experimental and nonexperimental estimates, Jeffrey R. Kling, Jeffrey B. Liebman, and Katz (2007) do not find evidence of upward bias from nonrandom sorting of households across neighborhoods, as would occur under assumption that persons with good unobservables also have good outcomes and live in a good neighborhood. A similar finding is reported by Goux and Maurin (2007) in their analysis of neighborhood effects on early performance at school.
} 
Table 7-Variation in OLS and IV Estimates of the Effect of Neighbors' LM Participation on Own LM Participation Across Sub-Samples

\begin{tabular}{|c|c|c|c|c|c|c|}
\hline & \multicolumn{2}{|c|}{ Full sample } & \multicolumn{2}{|c|}{$\begin{array}{c}\text { Number of other mothers } \\
\text { in the aire - } 4\end{array}$} & \multicolumn{2}{|c|}{$\begin{array}{c}\text { Number of other mothers } \\
\text { in the aire } 0 \text { - } 8\end{array}$} \\
\hline & $\begin{array}{l}\text { OLS } \\
(1)\end{array}$ & $\begin{array}{l}\text { IV } \\
(2)\end{array}$ & $\begin{array}{l}\text { OLS } \\
\text { (3) }\end{array}$ & $\begin{array}{l}\text { IV } \\
(4)\end{array}$ & $\begin{array}{l}\text { OLS } \\
(5)\end{array}$ & $\begin{array}{l}\text { IV } \\
(6)\end{array}$ \\
\hline $\begin{array}{l}\text { Proportion participating } \\
\text { in the LM }\end{array}$ & $\begin{array}{c}0.17 \\
(0.01)\end{array}$ & $\begin{array}{c}0.59 \\
(0.30)\end{array}$ & $\begin{array}{c}0.32 \\
(0.02)\end{array}$ & $\begin{array}{c}0.75 \\
(0.31)\end{array}$ & $\begin{array}{c}0.52 \\
(0.03)\end{array}$ & $\begin{array}{c}0.75 \\
(0.83)\end{array}$ \\
\hline Observations & 31,311 & 31,311 & 16,492 & 16,492 & 5,301 & 5,301 \\
\hline
\end{tabular}

notes: Sample: Women aged 21-35 years old with two or more children. Standard errors (in parentheses) are adjusted for potential serial and spatial correlation at the "aire" level.

Source: LFS 1990-2001, Insee.

on the OLS estimate. Assuming that the variance in the error affecting our measurement of neighbors' average participation decreases with the number of other mothers who are actually observed in the aire, the bias should decrease with the number of other mothers observed in the aire.

If this interpretation is correct, the difference between the OLS and the IV estimates should also decrease when focusing on neighborhoods with more mothers. This is actually what we observe. The OLS estimate is three times as large (0.52) when we restrict the sample to neighborhoods with at least 9 neighbors, whereas the IV estimate remains unchanged when the number of mothers in the neighborhood increases (even though it becomes more imprecise as the number of observations becomes smaller).

\section{A re-evaluation Using child Quarter of Birth as an Instrument}

This section compares the evaluation of social interactions produced using the "sex-mix" instrument to evaluations obtained with the distribution of children's quarter of birth as a source of identification. Specifically, our second strategy builds on the fact that mothers whose children were born at the end of the year participate less in the labor market than other mothers.

This relationship between a child's quarter of birth and maternal labor supply was first used by Gelbach (2002) in his contribution on the causal effect of preschool availability on mothers' outcomes in the United States. We find a similar relationship in France. In both countries, mothers whose children were born at the end of the year have to wait longer before their children start school, and it is one plausible reason for their lower labor market participation. ${ }^{14}$ French children born at the end of the year are also the youngest of their year-group and, as a consequence, are those

\footnotetext{
${ }^{14}$ French children start preschool either in September of the year of their second birthday (early start) or in September of the year of their third birthday (normal start). With respect to early start, a priority is given to more mature children, i.e., born earlier in the year. According to the French census conducted in 1999, the early enrollment rate is about 70 percent for children born in January and only about 20 percent for children born in December.
} 
for whom adaptation to school is by far the most difficult. ${ }^{15}$ According to a survey conducted in 1997 by the French Ministry of Education, the proportion of mothers who think that their child is not gifted at schoolwork and the proportion indicating that they help with homework on a regular basis is significantly larger when the child was born during the last quarter of the year. The proportion of pupils who are held back a grade in primary school is actually about twice as large for pupils born during the last quarter of the year than it is pupils born during the first quarter of the year ${ }^{16}$ (16.5 percent versus 9 percent, see Julien Grenet 2005). These school adaptation problems represent another plausible explanation for the relatively low participation of mothers whose children were born at the end of the year. There is a related literature showing that children's health problems negatively affect mothers' labor market participation (see, e.g., Elizabeth T. Powers 2001) and school adaptation problems may have similar effects.

When we focus on the sample of mothers with two or more children, our data confirm that those whose second child was born at the end of the year participate significantly less in the labor market than the other mothers (see Table 8, panel A). This participation gap cannot be explained by variation in the season of childbirth across mothers with different backgrounds. As a matter of fact, mothers whosesecond child was born during the last quarter of the year are neither more educated nor more often non-French than other mothers (see Table 2, panel B). They do not have a larger number of children either. When we regress mother's labor market participation on quarter of birth, the estimated effect of second child's quarter of birth is almost exactly the same (i.e., 1.7 percentage points) regardless of whether or not we control for mother's education, age, and nationality ${ }^{17}$ (not reported). By construction, the quarter of birth of the second child is the most recent quarter-ofbirth "shock" that has affected all mothers with two or more children. This is why we focus on this specific quarter of birth. We have checked that the correlation is actually negligible between participation and the quarter of birth of the first child.

Also, the LFS data do not reveal any specific residential concentration of families whose second child was born at the end of the year. The distribution of families whose second child was born at the end of the year across neighborhoods is not distinguishable from random assignment (see Table 9). Further analysis confirms that the average characteristics of neighbors are actually very similar for mothers whose second child was born during the last quarter of the year and for the other mothers (not reported).

\footnotetext{
${ }^{15}$ After preschool, all children start elementary school in September of the year of their sixth birthday, regardless of whether they benefited from an early start. In this context, children born at the end of the year spend on average less time in preschool (they typically start one year later, but finish at the same date) and are the youngest and the least mature of their year-group in elementary school.

${ }^{16}$ The national evaluations conducted at entry into third grade of elementary school show an average difference of about $1 / 2$ of a standard deviation between scores of children born in January and those of children born in December.

${ }^{17}$ Further analysis shows that participation differences between mothers of children born during the last quarter of the year and other mothers is 2.5 percentage points (s.e. 50.9 ) when children are in preschool. The difference is almost exactly the same when children are in elementary school. In contrast the difference is negligible for children who have not yet started school and is only 1 percentage point (s.e. 5 2.5) for children in secondary education. These results are consistent with the assumption that the effect of quarter of birth on maternal participation reflects an effect on the date of entry into (and on the problems of adapting to) primary school.
} 
Table 8-The Quarter of Birth of Children and Mothers’ Labor Market Participation, by Education Groups

\begin{tabular}{|c|c|c|c|}
\hline & $\begin{array}{c}\text { All } \\
(1)\end{array}$ & $\begin{array}{l}\text { High school dropouts } \\
(2)\end{array}$ & $\begin{array}{l}\text { High school graduates } \\
\text { (3) }\end{array}$ \\
\hline $\begin{array}{l}\text { panel A: own children } \\
\text { (a) Second birth last quarter }\end{array}$ & $\begin{array}{c}0.584 \\
(0.005)\end{array}$ & $\begin{array}{c}0.522 \\
(0.007)\end{array}$ & $\begin{array}{c}0.737 \\
(0.009)\end{array}$ \\
\hline $\begin{array}{l}\text { (b) Second birth in } \\
\text { quarter } 123\end{array}$ & $\begin{array}{c}0.601 \\
(0.003)\end{array}$ & $\begin{array}{c}0.547 \\
(0.004)\end{array}$ & $\begin{array}{c}0.736 \\
(0.005)\end{array}$ \\
\hline difference $(a) 2(b)$ & $\begin{array}{r}20.017 * \\
(0.006)\end{array}$ & $\begin{array}{r}20.025 * \\
(0.008)\end{array}$ & $\begin{array}{c}0.001 \\
(0.010)\end{array}$ \\
\hline \multirow[t]{2}{*}{ Observations } & 31,311 & 22,275 & 9,036 \\
\hline & $\begin{array}{l}\text { All } \\
(1)\end{array}$ & $\begin{array}{l}\text { Some high school dropouts } \\
\text { in the neighborhood } \\
\text { (2) }\end{array}$ & $\begin{array}{l}\text { No high school dropouts } \\
\text { in the neighborhood } \\
\text { (3) }\end{array}$ \\
\hline $\begin{array}{l}\text { panel B: neighbors’ children } \\
\text { (c) Prop. second birth last } \\
\text { quarter }-0.40\end{array}$ & $\begin{array}{c}0.588 \\
(0.006)\end{array}$ & $\begin{array}{c}0.582 \\
(0.006)\end{array}$ & $\begin{array}{c}0.649 \\
(0.018)\end{array}$ \\
\hline $\begin{array}{l}\text { (d) Prop. second birth last } \\
\text { quarter } 50\end{array}$ & $\begin{array}{c}0.614 \\
(0.005)\end{array}$ & $\begin{array}{c}0.609 \\
(0.005)\end{array}$ & $\begin{array}{c}0.639 \\
(0.012)\end{array}$ \\
\hline difference $(c) 2(d)$ & $\begin{array}{r}20.025 * \\
(0.006)\end{array}$ & $\begin{array}{r}20.027 * \\
(0.008)\end{array}$ & $\begin{array}{c}0.010 \\
(0.022)\end{array}$ \\
\hline Observations & 31,311 & 28,852 & 2,459 \\
\hline
\end{tabular}

notes: Sample: Women aged 21-35 years old with two or more children. The second column of panel A analyzes mothers who are high school dropouts. Their participation rate is 0.522 when their second child was born during the last quarter of the year. The third column of panel B analyzes mothers whose neighbors are all high school graduates. Their participation rate is 0.649 when the proportion of neighbors whose second child was born during the last quarter is above 0.40 (which corresponds to the top quartile of the distribution of this proportion). Standard errors are in parentheses.

* Significance at the 95 percent confidence level.

Source: LFS 1990-2001, Insee.

Given these facts, variation across neighborhoods in the proportion of mothers whose children were born at the end of the year represents another possible source of identification of neighbors' influence. Does the labor market participation of a mother decrease when the children of her close neighbors were born at the end rather than at the beginning of the year? Interestingly enough, our data reveal that the probability of a mother's participation is actually 2.5 percentage points higher when the (second) child of her neighbors were born at the beginning of the year rather than in the opposite case (Table 8, panel B).

Also, we observe the same pattern for the quarter-of-birth instrument as for the children sex-mix instrument. The effect of a child's quarter of birth on his/her mother's labor market participation is significant and large for less educated mothers only (2.5 percentage points). The effect is negligible for more educated mothers. In this context, the question is whether or not the influence of the quarter of birth of neighbors' children on a mother depends on neighbors' education. To address this issue, we have compared the effect of the quarter of birth of neighbors' children when neighbors are educated and when they are less educated. Most interestingly, the effect is significant only in the noneducated case, i.e., only when quarter of birth of neighbors' children affects their neighbors' behavior (Table 8, panel B). 
Table 9-The Distribution of Neighborhoods According to the Number of Mothers whose Second Child was Born in the Last Quarter of the Year and its Distance to Random Assignment

\begin{tabular}{|c|c|c|c|}
\hline \multirow[b]{2}{*}{$\begin{array}{l}\text { Number of mothers with } \\
\text { second child born last quarter }\end{array}$} & \multicolumn{3}{|c|}{$\begin{array}{l}\text { Distribution of neighborhoods according to the number of mothers whose } \\
\text { second child was born during the last quarter of the year }\end{array}$} \\
\hline & $\begin{array}{c}\text { Observed distribution of } \\
\text { neighborhoods } \\
\text { ( } p \text {, in percent) } \\
(1)\end{array}$ & $\begin{array}{l}\text { Distribution under random } \\
\text { assignment assumption } \\
\text { ( } p_{0} \text {, in percent) } \\
\text { (2) }\end{array}$ & $\begin{array}{c}\mathrm{x}^{2} \\
\left(p \underset{(3)}{2 p_{0}}\right)^{2} / p_{0}\end{array}$ \\
\hline 0 & 37.53 & 37.44 & 0.01 \\
\hline 1 & 36.83 & 36.88 & 0.005 \\
\hline 2 & 17.06 & 16.85 & 0.20 \\
\hline 3 & 5.36 & 5.52 & 0.35 \\
\hline 4 et 1 & 3.22 & 3.31 & 0.19 \\
\hline $\begin{array}{l}\mathrm{x}^{2} \text { stat. } \\
(p \text {-value })\end{array}$ & - & - & $\begin{array}{c}0.75 \\
(0.95)\end{array}$ \\
\hline
\end{tabular}

notes: Sample: Women aged 21-35 years old two or more children (n 5 31,311). The observed proportion of neighborhoods without any "last-quarter" families is 0.3753 . The proportion would be 0.3744 if "last-quarter" families were randomly assigned across neighborhoods. A chi-squared test does not reject the random assignment assumption.

Source: LFS 1990-2001, Insee.

We have also compared the effect of the "quarter-of-birth" instrument before and after the reform of family benefits. Again, we have found exactly the same results as with the "same-sex" instrument. ${ }^{18}$ The new instrument has a significant impact on a mother's behavior before the reform only, and it is also only before the reform that it affects neighbors' behavior (not reported).

Finally, we have checked that there is no difference in the labor market participation of fathers, or in the labor market participation of women without children, with respect to the quarter of birth of neighbors' children (not reported). These results are consistent with the assumption that a mother is influenced by the quarter of birth of neighbors' children because of social interactions and not because of correlated neighborhood effects.

Overall, we have an array of findings suggesting that the quarter of birth of neighbors' children affects a mother's behavior only insofar as it affects their own behavior. Under this assumption, it is possible to identify the influence of neighbors' participation on a mother's participation, using the "quarter-of-birth" instrument (and its interaction with either mothers' education or reform status) rather than the "same sex" one. Generally speaking, when we replicate the full econometric analysis with this new instrument, we obtain estimates that are very similar to those obtained in the previous section with the "same-sex" instruments. Table 10 reports a set of estimates where we jointly use the "same-sex" and "quarter-of-birth" instruments to identify the influence of neighbors' labor market participation on a mother's

\footnotetext{
${ }^{18}$ As discussed above, the reform has modified the marginal group of mothers potentially affected by our instruments, i.e., they have higher potential wages after the reform. In this context, the fact that the quarter-ofbirth instrument has a smaller effect after the reform is consistent with the fact that it has a smaller effect on decisions taken by mothers with higher potential wages.
} 
Table 10-Comparison of the "Sex Mix" $\left(Z_{1}\right)$ and "Quarter of Birth” $\left(Z_{2}\right)$ Instruments

\begin{tabular}{|c|c|c|c|c|c|c|}
\hline & \multirow[b]{2}{*}{ First stage } & \multicolumn{5}{|c|}{ Dependent variable: LM participation } \\
\hline & & $\begin{array}{l}\text { Reduced } \\
\text { form } \\
\text { (2) }\end{array}$ & $\begin{array}{c}\text { IV } \\
Z_{1} \text { and } Z_{2} \\
\text { (3) }\end{array}$ & $\begin{array}{l}\text { IV } \\
Z_{1} \\
(4)\end{array}$ & $\begin{array}{l}\text { IV } \\
Z_{2} \\
(5)\end{array}$ & $\begin{array}{l}\text { IV } \\
Z_{2} \\
(6)\end{array}$ \\
\hline Proportion participating in the LM & - & - & $\begin{array}{l}0.684^{*} \\
(0.251)\end{array}$ & $\begin{array}{c}0.585^{*} \\
(0.299)\end{array}$ & $\begin{array}{c}0.906^{*} \\
(0.444)\end{array}$ & $\begin{array}{l}0.925^{*} \\
(0.430)\end{array}$ \\
\hline Proportion same sex & $\begin{array}{r}20.036 * \\
(0.008)\end{array}$ & $\begin{array}{c}20.020 * \\
(0.010)\end{array}$ & - & - & - & - \\
\hline $\begin{array}{l}\text { Proportion second birth } \\
\text { last quarter }\end{array}$ & $\begin{array}{r}20.032 * \\
(0.010)\end{array}$ & $\begin{array}{r}20.029 * \\
(0.012)\end{array}$ & - & - & - & - \\
\hline Three children or more & - & - & - & - & - & $\begin{array}{r}20.282 * \\
(0.167)\end{array}$ \\
\hline $\begin{array}{l}\text { Over-id. test } \\
\text { Sargan stat. }(p)\end{array}$ & - & - & $\begin{array}{c}0.472 \\
(0.492)\end{array}$ & - & - & - \\
\hline Observations & 31,311 & 31,311 & 31,311 & 31,311 & 31,311 & 31,311 \\
\hline
\end{tabular}

notes: Sample: Women aged 21-35 years old with two or more children. All regressions include the same control variables as in model (3) of panel C in Table 6. Regressions using the proportion of neighbors whose second child was born during the last quarter of the year $\left(Z_{2}\right)$ as an instrumental variable also include mother's age, a dummy indicating that the second birth was during the last quarter of the year, an interaction between this dummy and a dummy indicating that the second birth was after the reform, the proportion of neighbors whose second child was born after the reform and during the last quarter of the year, as additional control variables. The standard errors (in parentheses) are adjusted for serial and spatial correlation at the "aire" level and * denotes significance at the 95 percent confidence level.

Source: LFS 1990-2001, Insee.

participation (using the same specification as in the third model of Table 6). The first two columns show that the two instruments have similar effects not only on the mother's participation (reduced form), but also on the participation of her neighbors (first stage). The third column shows the results of the corresponding IV regressions. They are not significantly different from those obtained when we use the "same-sex" instrument alone (column 4) or the "quarter-of-birth" instrument alone (columns 5 and 6). Standard over identification tests do not reject the internal validity of our approach.

\section{VI. . Conclusion}

A mother's decision to participate in the labor market is correlated with those of the other mothers living in the same neighborhood. This paper studies the extent to which this is causal. Our identifying strategy uses instrumental variables. In France, a mother's children sex mix has a significant impact on her decision to participate in the labor market. In contrast, the sex mix does not have any perceptible effect on neighborhood choice. Given these facts, the children sex mix of neighbors provides us with a plausible instrument to identify the effect of neighbors' labor market participation on a mother's labor market participation. Interestingly enough, the reduced-form analysis shows a significant influence of neighbors' children sex mix on own participation and the corresponding IV estimate suggests a significant elasticity of own participation to neighbors participation, even though the precise 
size of the effect is difficult to estimate. We compare this result to estimates produced using the distribution of children's quarters of birth to generate instruments. Mothers whose children were born during the last quarter of the year cannot send their children to primary school as early as the other mothers and participate less in the labor market. Estimates using the distribution of quarters of birth in the neighborhood as instruments are as strong as estimates using the sex-mix instrument. It is worth emphasizing that our instruments do not have any significant effect on the labor market participation of fathers nor on the labor market participation of women without children, which is clearly consistent with the assumption that a mother is influenced by the sex (or quarter of birth) of the siblings of the other mothers living in the neighborhood only through social interactions and not because of correlated neighborhood effects.

Understanding variation in women's labor supply across areas and over time is a very difficult task. This paper suggests that one plausible explanation is the existence of a significant social multiplier, where the utility of not working is strongly linked to the proportion of close neighbors who do not work.

\section{REFERENCES}

Alesina, Alberto, Edward L. Glaeser, and Bruce L. Sacerdote. 2006. "Work and Leisure in the US and Europe: Why so Different?” In NBER macroeconomics Annual 2005, Mark Gertler and Kenneth Rogoff, 1-64. Cambridge, MA: MIT Press.

Angrist, Joshua D., and William N. Evans. 1998. "Children and Their Parents' Labor Supply: Evidence from Exogenous Variation in Family Size.” American Economic review, 88(3): 450-77.

Case, Anne C., and Lawrence F. Katz. 1991. "The Company You Keep: The Effects of Family and Neighborhood on Disadvantaged Youths.” National Bureau of Economic Research Working Paper 3705.

Cooper, Russell, and Andrew John. 1988. "Coordinating Coordination Failures in Keynesian Models.” Quarterly Journal of Economics, 103(3): 441-63.

Del Boca, Daniela, Marilena Locatelli, and Silvia Pasqua. 2000. "Employment Decisions of Married Women: Evidence and Explanations.” Labour, 14(1): 3552.

Dietz, Robert. 2001. "Estimation of Neighbourhood Effects in the Social Sciences: An Interdisciplinary Approach.” Social Sciences research, 31(4): 539-75.

Durlauf, Steven N. 2004. "Neighborhood Effects." In handbook of regional and Urban Economics. Vol. 4, ed. J. Vernon Henderson and Jacques-Francois Thisse, 2172-2242 Amsterdam: North Holland.

Fernandez, Raquel, Alessandra Fogli, and Claudia Olivetti. 2004. "Mothers and Sons: Preference Formation and Female Labor Force Dynamics." Quarterly Journal of Economics, 119(4): 1249-99.

Gelbach, Jonah B. 2002. "Public Schooling for Young Children and Maternal Labor Supply.” American Economic review, 92(1): 307-22.

Glaeser, Edward L., Bruce I. Sacerdote, and Jose A. Scheinkman. 2003. "The Social Multiplier." Journal of the European Economic Association, 1(2-3): 345-53. 
Goering, John, Judith D. Feins, and Todd M. Richardson. "A Cross-Site Analysis of Initial Moving to Opportunity Demonstration Results." Journal of housing research, 13(1): $1-30$.

Goldin, Claudia. 2006. "The Quiet Revolution That Transformed Women's Employment, Education, and Family.” National Bureau of Economic Research Working Paper 11953.

Goldin, Claudia, and Lawrence F. Katz. 2002. "The Power of the Pill: Oral Contraceptives and Wom- en's Career and Marriage Decisions." Journal of political Economy, 110(4): 730-70.

Goux, Dominique, and Eric Maurin. 2005. "The Effect of Overcrowded Housing on Children's Performance at School.” Journal of public Economics, 89(5-6): 797-819.

Goux, Dominique, and Eric Maurin. 2007. "Close Neighbours Matter: Neighbourhood Effects on Early Performance at School.” Economic Journal, 117(523): 1193-1215.

Grenet, Julien. 2005. "Pourquoi les Taureaux sont-ils mieux payés que les Capricornes? L’impact économique de la date de naissance.” Unpublished.

Grodner, Andrew, and Thomas J. Kniesner. 2006. “An Empirical Model of Labor Supply with Social Interactions: Econometric Issues and Tax Policies Implications." Unpublished.

Héran, François. 1986. “Comment les Français voisinent." Economie et Statistique, (195): 43-59.

Ioannides, Yannis M. 2002. "Residential Neighborhood Effects." regional Science and Urban Economics, 32(2): 145-65.

Ioannides, Yannis M. 2003. "Interactive Property Valuations.” Journal of Urban Economics, 53(1):145-70.

Ioannides, Yannis M., and Jeffrey E. Zabel. 2003. "Neighbourhood Effects and Housing Demand.” Journal of Applied Econometrics, 18(5): 563-84.

Kling, Jeffrey R., Jeffrey B. Liebman, and Lawrence F. Katz. 2007. "Experimental Analysis of Neighborhood Effects.” Econometrica, 75(1): 83-119.

Manski, Charles F. 1993. "Identification of Endogenous Social Effects: The Reflection Problem.” Review of Economic Studies, 60(3): 531-42.

Neumark, David, and Andrew Postlewaite. 1998. "Relative Income Concerns and the Rise in MarriedWomen's Employment.” Journal of public Economics, 70(1): 157-83.

Oreopoulos, Philip. 2005. "Neighbourhood Effects in Canada: A Critique." Unpublished.

Piketty, Thomas. 2005. "L'impact de l'allocation parentale d'éducation sur l'activité féminine et la fécondité en France, 1982-2002" In histoires de familles, histoires familiales, ed. Cécile Lefèvre, 79-109. Paris: Les Cahiers de l'Ined.

Powers, Elizabeth T. 2001. "New Estimates of the Impact of Child Disability on Maternal Employ- ment.” American Economic review, 91(2): 135-39.

Rosenzweig, Mark R., and Kenneth I. Wolpin. 2000. "Natural "Natural Experiments' In Economics.” Journal of Economic Literature, 38(4): 827-74.

Solon, Gary, Marianne E. Page, and Greg J. Duncan. 2000. "Correlations between Neighboring Chil-dren in Their Subsequent Educational Attainment." Review of Economics and Statistics, 82(3): 383-92. 
Woittiez, Isolde, and Arie Kapteyn. 1998. "Social Interactions and Habit Formation in a Model of Female Labour Supply.” Journal of public Economics, 70(2): 185-205. 


\section{University Library}

\section{- M M I N E R VA A gateway to Melbourne's research publications}

Minerva Access is the Institutional Repository of The University of Melbourne

Author/s:

Maurin, E;MOSCHION, J

Title:

The Social Multiplier and Labor Market Participation of Mothers

Date:

2009

Citation:

Maurin, E. \& MOSCHION, J. (2009). The Social Multiplier and Labor Market Participation of Mothers. American Economic Journal: Applied Economics, 1 (1), pp.251-272. https:// doi.org/10.1257/app.1.1.251.

Persistent Link:

http://hdl.handle.net/11343/127409 